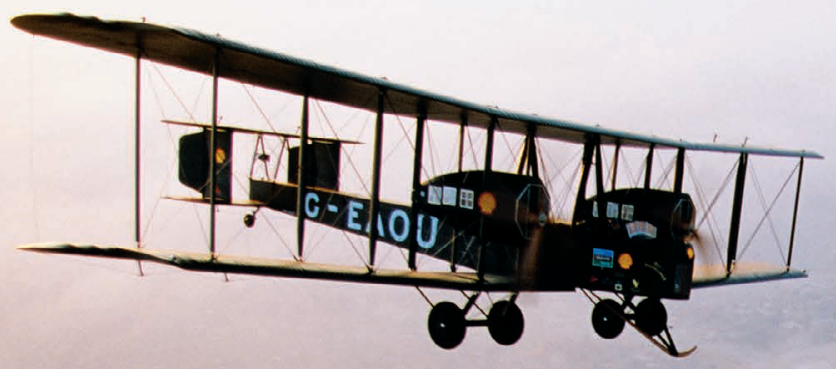

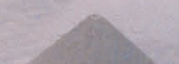
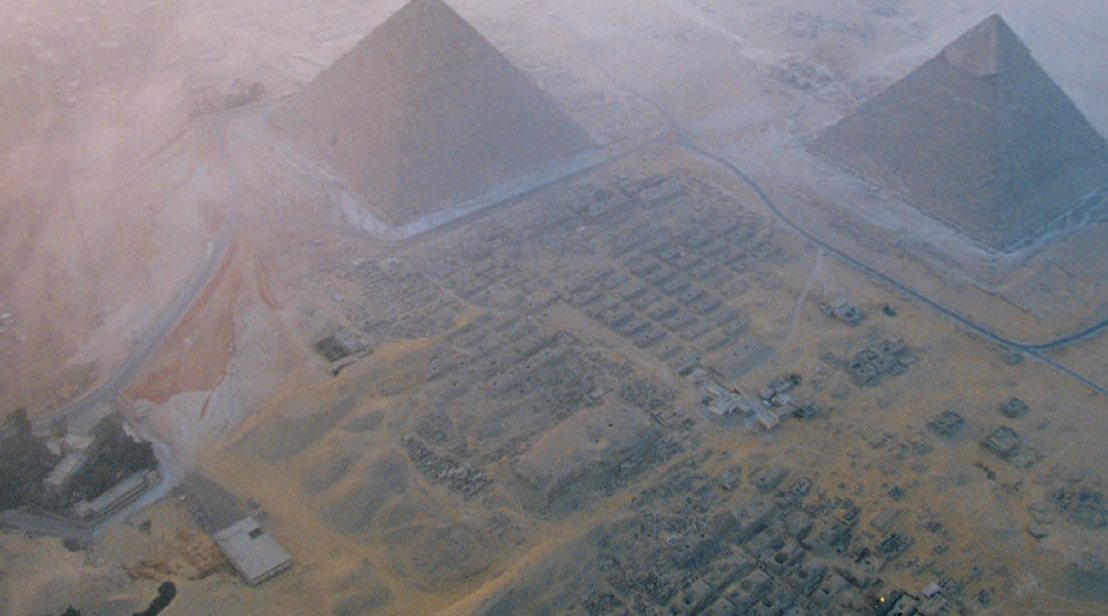

An aeroplane flies over the pyramids and Sphinx on the Giza Plateau near Cairo.

ARCHAEOLOGY

\title{
The wonder of the pyramids
}

\section{Andrew Robinson enjoys a volume rounding up research on the complex at Giza, Egypt.}

\section{$\mathrm{I}$}

n Giza and the Pyramids, veteran Egyptologists Mark Lehner and Zahi Hawass cite an Arab proverb: "Man fears time, but time fears the pyramids." It's a reminder that the great Egyptian complex on the Giza Plateau has endured for some four and a half millennia - the last monument standing of that classical-era must-see list, the Seven Wonders of the World.

Lehner and Hawass have produced an astonishingly comprehensive study of the excavations and scientific investigations that have, over two centuries, uncovered the engineering techniques, religious and cultural significance and other aspects of the Giza site. Three decades in the making, the book has undergone many iterations in step with new findings, from tombs to data gleaned from the study of clay sealings, plant remains, bakeries, abattoirs and workshops.

Both authors have been deeply involved with the site since the mid-1970s, and they often openly agree to disagree on interpretations of evidence. Lehner began studying Giza under the aegis of the Stanford Research Institute in California, later founding the nonprofit organization Ancient Egypt Research Associates. Hawass served as Giza's governmental chief inspector and, in 2011, as Egypt's first Minister of Antiquities under President

Hosni Mubarak. After Mubarak fell from power during the Arab Spring that year, Hawass resigned, amid controversy.

The Giza complex invites speculation and debate. Its three pyramids are the tombs of pharaohs Khufu, Khafre and Menkaure, also known as Cheops, Chephren and Mycerinus,

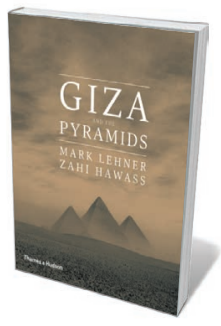

Giza and the Pyramids

MARK LEHNER \& ZAHI HAWASS

Thames \& Hudson: 2017.
AERAGRAM 16(2), 8-14; 2015), the tomb's four sides, each a little more than 230 metres long, vary by at most just 18.3 centimetres.

Lehner and Hawass reject the idea that armies of Egyptian slaves constructed the pyramids, as the classical Greek historian Herodotus suggested. They do, however, embrace the concept that the innovative administrative and social organization demanded by the enormous task of building the complex were key factors in creating Egyptian civilization.

The authors are also in accord over a theory regarding the purpose of the Giza monuments. Lehner noticed that if you stand near the Sphinx during the summer solstice, the Sun appears to set midway between the pyramids of Khufu and Khafre, visually echoing a hieroglyph that symbolizes the cycle of life and rebirth. Along with other astronomical evidence, this has led him and Hawass to speculate that the progenitors of the complex saw it as a "cosmic engine" - a way of harnessing the power of the sun god Ra to resurrect the soul of the entombed pharaoh (see go.nature.com/2xupsis).

The hundreds of illustrations in the book - from hieroglyphic inscriptions to laser scans - reveal other marvels. Photographs of the inner chambers, cores and outer 
masonry of the pyramids show intriguing details. The inner masonry (which on Khufu's pyramid was originally faced with polished white limestone) is surprisingly irregular and full of holes, "analogous to Swiss cheese". All three pyramids are now being investigated, using muon tomography and infrared thermography, for the presence of internal voids - a project of international consortium ScanPyramids under the authority of Egypt's Ministry of Antiquities. The group has located two possible cavities of as-yetunknown significance in the Great Pyramid.

A fascinating discovery by Lehner and Hawass centres on the funerary monument of Khentkawes, a queen with complicated royal connections who may have ruled during the fourth dynasty, the Old Kingdom's 'golden age'. Drilling cores into a depression east of this complex in 2009-14, the team hit a hard surface below the estimated level of the Nile Valley floodplain in that dynasty. They posit that this may be evidence of a functioning harbour - a "pyramid port" that filled during the annual inundation. (Floods could reach the foot of the plateau before 1902, when the first Aswan dam was completed.)

So, did the pyramid builders ship in stone by river? That is supported by papyrus rolls found in 2011-13 by French archaeologist Pierre Tallet and his team, who were excavating a port complex of Khufu at Wadi el-Jarf on the Red Sea. These contain the hieroglyphic journal of a pyramid builder named Merer and accounts of provisions for his team. Hailed by Hawass as "the greatest discovery in Egypt in the twenty-first century" (see go.nature.com/2y1rneg), the papyri detail the building of the Great Pyramid. They describe workers delivering limestone to Giza by boat from quarries at Turah, halfway between modern Cairo and Helwan. As in the nineteenth century, archaeological techniques combined with ancient manuscripts are advancing Egyptology.

Those investigations began with the scientific savants of Napoleon Bonaparte's Egyptian expedition at the turn of the nineteenth century, and were revolutionized by Jean-François Champollion's decipherment of hieroglyphics in the 1820 s (A. Robinson Nature 468, 632-633; 2010). But as this monumental book shows, speculation continues to swirl around much of the evidence, ranging from the motivation behind Khufu's design to the practicalities of transporting 50-tonne stones and manoeuvring them into place. It looks as if the Giza pyramids - three vast megalomaniacal puzzle boxes guarded by the enigmatic Sphinx - will continue to tantalize researchers in engineering, climate change and philology for generations to come.

Andrew Robinson is the author of

Cracking the Egyptian Code.

e-mail:andrew@andrew-robinson.org

\section{Books in brief}

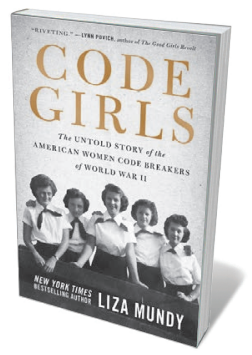

Code Girls

Liza Mundy HACHETTE (2017)

After the United States' abrupt entry into the Second World War in 1941 , its military recruited a shadow army of code breakers. More than 10,000 talented female mathematicians and linguists joined their ranks. As Liza Mundy reveals in this astonishing chronicle, this elite corps helped to shorten the war, building the field of cybersecurity. Mundy, who mined US National Security Agency archives and interviewed survivors for the book, joins authors such as Margot Lee Shetterly and Nathalia Holt in giving the women behind great twentieth-century scientific endeavours their due.

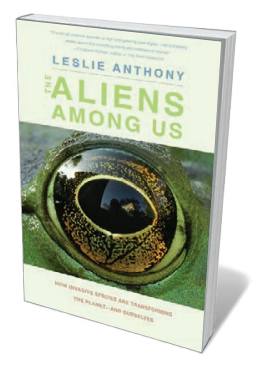

The Aliens Among Us

Leslie Anthony YALE UNIVERSITY PRESS (2017)

Whether it's Florida's Burmese pythons (Python bivittatus) or Asian carp in the Great Lakes, invasions of alien species in the United States are rising, just as many ecosystems reach critical vulnerability. Tracing the pattern of invasion from introduction to adaptation, biologist Leslie Anthony explicates the science amid interviews with researchers on the front line. He ably cuts through the complexities of controlling species such as Didymosphenia geminata (rock snot algae), and eloquently defines the existential dilemma at the heart of the issue: "They were alien, I was alien; they were nature, I was nature."

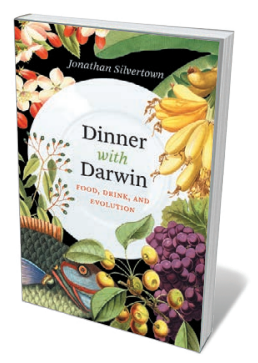

\section{Dinner with Darwin: Food, Drink, and Evolution}

Jonathan Silvertown UNIVERSITY OF CHICAGO PRESS (2017)

The Darwinian dining served up by evolutionary ecologist Jonathan Silvertown in this delectably erudite study is all about tracing the impact of natural selection on foods. We learn that mussels helped to fuel the hominin exodus from Africa; rye is a weed domesticated by accident; carnivory and tapeworms are intimately linked; and Penicillium camemberti mould evolved in soft cheeses. We even examine engastration - stuffing one animal into another before cooking - as a status-led manifestation of the need to share food. This intricate scientific banquet is a marvellous read: bon appétit.

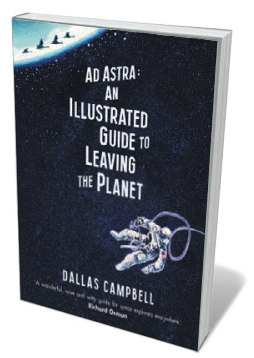

Ad Astra: An Illustrated Guide to Leaving the Planet

Dallas Campbell SIMON \& SCHUSTER (2017)

In this nifty melange of real and fictional attempts to leave Earth, the vintage images alone are worth the price of the ticket. But broadcaster Dallas Campbell's "deeply impractical guide" is all pretty space-tastic. It begins logically, with cosmonaut Yuri Gagarin's launch into orbit on 12 April 1961, and ends with the commercial propulsion of human ashes into space. In between are snippets such as a theme-park visit with AI Worden, pilot of the Apollo 15 command module; a history of spacesuits; astronaut Peggy Whitson's tortilla cheeseburger; and other fuel for imaginative lift-off.

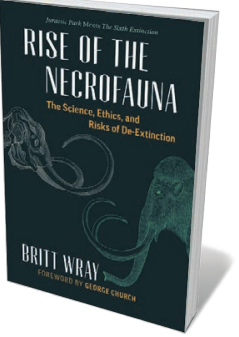

\section{Rise of the Necrofauna}

Britt Wray GREYSTONE (2017)

De-extinction is so hot a topic it sizzles. Science writer Britt Wray braves the heat for a neat overview of the science and its ethical and environmental implications. After explaining techniques for manipulating ancient DNA (cloning, CRISPR and selective breeding), Wray interviews a number of 'resurrection researchers' such as geneticist George Church of the Woolly Mammoth Revival project. The sceptics, including biologist Paul Ehrlich, add balance to Wray's tour of this hellishly complex, decidedly nascent field. Barbara Kiser 